\title{
E-Government Indicators - Getting to the Next Level
}

The UN Division for Public Administration and Development Management (DPADM) organized an expert meeting in December 2008 to review the UN EGovernment Survey and consider ways of "Getting to the Next Level." The Acting Director of DPADM, Ms. Haiyan Qian, stated the purpose of the meeting was to "expand and improve on the existing e-Government indicators." It was suggested that four new sets of indicators: citizen's usage of government online services, back office management in e-Government, inclusiveness of e-Government and mobile device usage for transacting with government, as well as an adding e-Participation. In addition the experts were asked to make suggestions to improve the survey methodology. See: http://unpan1.un.org/intradoc/groups.

The objectives to be achieved from the five new sets of indicators according to Ms. Haiyan Qian, are to "move beyond supply-side e-Government measurement and frontline assessment of e-Government activities." The indicators were described as follows:

1. "Usage - Usage indicators, for example, are not about just adding new indicators, they entail a fundamental change of perspective from supply-side assessment of e-Government. The importance of moving beyond the well established supply side measurement has thus far relied almost entirely on web-feature based measurements, hence, focusing on supply-side availability of e-Government. A demand-side approach to e-Government measurement is first of all about measuring the use of electronic services offered by the government (i.e. usage). The indicators here will expand questions of the benchmarking part of the Survey to encompass the demand side (e.g. e-government take-up by citizens). Instead of just measuring the online availability of government service, these indicators will help measure the extent to which e-government is actually used by its citizens.

2. Back Office Management - Another important change is embodied by the increased attention on back office management of e-Government. There seems a strong link between efficient government back office and e-Government experience by users. The work on back office measurement so far is limited. The newly developed sets of indicators will help assess back office processes, systems and organizational arrangements required to support efficient e-Government functions and better service delivery.

Against the often fragmented landscape of governmental organizations, these indicators address (beyond ICT issues and front-line services) the need for a full assessment and re-engineering of government institutions and knowledge management processes. This work is deemed essential, particularly in light of limitation to supply-side web feature analysis that the availability of online services does not say much about internal organization of governments.

In addition to these two indicators - which will help move beyond front line and supply side measurement I feel that there is a great need to address mobile device usage for transacting with government and digital inclusiveness, while also updating e-participation.

3. Mobile Device Usage for Transacting with Government: This is a relatively new dimension of e-Government. This dimension represents an important and rapidly growing opportunity for better public service delivery and communication. The indicators here will help identify Member States' current progress with mobile technology utilization. 
4. Digital Inclusiveness: Without an explicit focus on inclusive e-Applications, there is a danger of digital exclusion, resulting in the inequalities being exacerbated by e-government, between the "haves" and "have-nots," and particularly between privileged and marginalized groups.

5. E-Participation: Finally, in addition to develop these new sets of indicators, it also deems necessary to revisit e-Participation indicators. Many eParticipation indicators are already contained in the Survey. Yet, the idea is to improve them in response to new ways and means promoting citizens' engagement. They assess participatory aspects and tools. These are, for example, providing collaborative and communicative space, facilitating networks between citizens and government as well as among citizens, and engaging in consultations and e-Decision-making."

By way of background, the United Nations eGovernment Survey tracks progress of the 192 Member States on their ability to deliver citizen-centric public service and attain the Millennium Development Goals (MDG). It measures and compares their state of eGovernment readiness via a benchmarking tool, namely the Global E-Government Readiness Index. The index measures each Member State's use of the Internet and World Wide Web for provision of information, products and services, plus the level of telecommunications and human capital infrastructure development. The index is a composite measure made up of the following constituent indexes:

1. Telecommunications (connectivity) infrastructure index: It is a composite weighted average of five primary indices of PCs, Internet users, telephone lines, mobile phones and broadband (all indices, peer 100 persons/to be revised to households). The data are obtained from the ITU.

2. Human Capital Index: It is derived from the UN Development Program (UNDP) education index, which is a composite of the adult literacy rate and gross enrollment ratio with two thirds weight given to adult literacy and one third to the enrollment ratios.

3. Web Measure Index: It is based on a quantitative analysis of the 192 Member States' web presence/features. The primary site assessed is the National Portal or the official homepage of the government, along with the websites of five ministries (education, health, labor, social welfare and finance).

Underlying the index is the following five-stage model of progression of e-Government sophistication:

- Emerging presence: in this state e-Government is limited, offering basic information online. EGovernment provides sources of past and current public policy and governance information (e.g. policies, laws and regulations, reports and newsletters);

- Enhanced presence: in this state e-Government provides not only greater sources of information, but also e-Tools and e-Services (e.g. downloadable forms, downloadable database, e-mail communication.

- Transactional presence: Two-way interactive applications provide citizens with opportunities for online, financial and non-financial transactions (e.g. online filing of taxes, payment of public utilities, application for ID cards, birth certificates, licenses, e-voting, etc.

- Connected presence: The way governments operate changes, and there is better coherence, integration and coordination of processes and systems within and across government agencies. Government transforms itself into a connected entity. This is the most sophisticated level of online e-Government and is characterized by:

* Horizontal connections among government agencies;

* Vertical connections among central and local government agencies;

* Infrastructure connections with interoperability issues;

* Government-citizen connectivity; and

* Connections among various stakeholders (including government, private sector, academia, NGOs and civil society.

In order to avoid subjective value judgments, the Index is not designed to assess the services offered quantitatively; and the web measure index allows only for indicator variables denoting the presence/absence of specific website attributes. The resulting e-Government Readiness Rankings are a measure of the progress of a country relative to all other countries. 